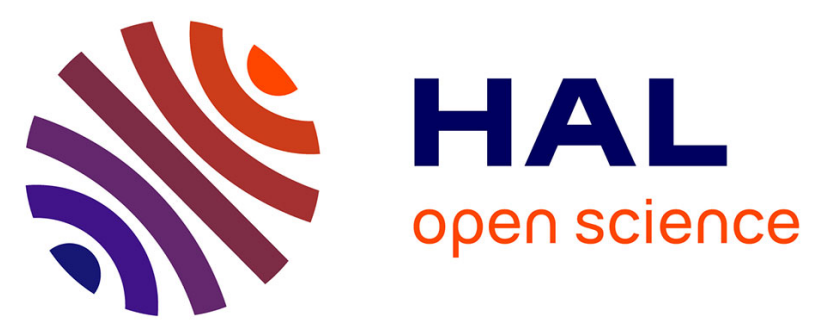

\title{
Synthesis of Discrete CHA Zeolite Nanocrystals without Organic Templates for Selective CO 2 Capture
}

\author{
Maxime Debost, Paul B. Klar, Nicolas Barrier, Edwin B. Clatworthy, Julien \\ Grand, Fabien Laine, Petr Brázda, Lukas Palatinus, Nikolai Nesterenko, \\ Philippe Boullay, et al.
}

\section{To cite this version:}

Maxime Debost, Paul B. Klar, Nicolas Barrier, Edwin B. Clatworthy, Julien Grand, et al.. Synthesis of Discrete CHA Zeolite Nanocrystals without Organic Templates for Selective CO 2 Capture. Angewandte Chemie International Edition, 2020, 59 (52), pp.23491-23495. 10.1002/anie.202009397. hal-03027983

\section{HAL Id: hal-03027983}

https://hal-normandie-univ.archives-ouvertes.fr/hal-03027983

Submitted on 27 Nov 2020

HAL is a multi-disciplinary open access archive for the deposit and dissemination of scientific research documents, whether they are published or not. The documents may come from teaching and research institutions in France or abroad, or from public or private research centers.
L'archive ouverte pluridisciplinaire HAL, est destinée au dépôt et à la diffusion de documents scientifiques de niveau recherche, publiés ou non, émanant des établissements d'enseignement et de recherche français ou étrangers, des laboratoires publics ou privés. 


\title{
Synthesis of discrete $\mathrm{CHA}$ zeolite nanocrystals without organic templates for selective $\mathrm{CO}_{2}$ capture
}

\author{
Maxime Debost, ${ }^{[a-b]}$ Paul B. Klar, ${ }^{[c]}$ Nicolas Barrier, ${ }^{[b]}$ Edwin B. Clatworthy ${ }^{[a]}$ Julien Grand ${ }^{[a-d]}$ Fabien \\ Laine, ${ }^{[b]}$ Petr Brázda, ${ }^{[c]}$ Lukas Palatinus, ${ }^{[c]}$ Nikolai Nesterenko, ${ }^{[d]}$ Philippe Boullay, ${ }^{*[b]}$ and Svetlana \\ Mintova*[a]
}

[a] Dr. M. Debost, Dr. E. B. Clatworthy, Dr. J. Grand, Dr.S.Mintova,

Normandie Université, ENSICAEN, UNICAEN, CNRS, LCS, 14000 Caen, France

[b] Dr. N. Barrier, Dr. F. Laine, Dr. P. Boullay

Normandie Université, ENSICAEN, UNICAEN, CNRS, CRISMAT, 14000 Caen, France

[c] Dr. P. B. Klar, Dr. P. Brázda, Dr. L. Palatinus

Institute of Physics of the Czech Academy of Sciences, Na Slovance 2, Prague, Czech Republic

[d] Dr. N. Nesterenko

Total Research and Technologies, Feluy, B-7181 Seneffe, Belgium

\begin{abstract}
Small-pore zeolites such as chabazite $(\mathrm{CHA})$ are excellent candidates for the selective separation of $\mathrm{CO}_{2}$, however, the current synthesis involves several steps and the use of organic structuredirecting agent (OSDA), increasing their cost and energy requirements. Here we report the synthesis of small-pore zeolite crystals (aluminosilicate) with CHA-type framework structure by direct synthesis in a colloidal suspension containing a mixture of inorganic cations only $\left(\mathrm{Na}^{+}, \mathrm{K}^{+}\right.$and $\left.\mathrm{Cs}^{+}\right)$. The location of $\mathrm{CO}_{2}$ molecules in the host structure was revealed by $3 D$ electron diffraction (3D ED). The high sorption capacity for $\mathrm{CO}_{2}(3.8 \mathrm{mmol} / \mathrm{g}$ at $121 \mathrm{kPa})$, structural stability and regenerability of the discreate $\mathrm{CHA}$ zeolite nanocrystals is maintained for 10 consecutive cycles without any visible degradation. The $\mathrm{CHA}$ zeolite $(\mathrm{Si} / \mathrm{Al}=2)$ reaches an almost perfect $\mathrm{CO}_{2}$ storage capacity $\left(8 \mathrm{CO}_{2}\right.$ per unit cell) and high selectivity $\left(\right.$ no $\mathrm{CH}_{4}$ was adsorbed).
\end{abstract}

The development of affordable and energy-efficient materials for the chemical and petrochemical industry is crucial as this sector is the largest consumer of energy and the third largest direct emitter of greenhouse gases. ${ }^{[1,2]}$ The demand for new materials for $\mathrm{CO}_{2}$ capture or separation from natural gas is of significant importance. New effective sorbents are expected to meet many important criteria such as high capacity, selectivity and stability, as well as recyclability and fast kinetics. ${ }^{[3,4]}$ Small-pore zeolites are attractive candidates because of the shape and size and of the pores, as well as the presence of extra-framework cations. ${ }^{[5]}$ By blocking the pore entries, the extraframework cations selectively provide access for molecules to the zeolite channels and cages depending on the nature of the molecules. ${ }^{[6]} \mathrm{A}$ high selectivity towards $\mathrm{CO}_{2}$ over $\mathrm{CH}_{4}$ for small-pore zeolites with $\mathrm{RHO}, \mathrm{MER}$ and $\mathrm{CHA}$ type framework has been observed, indicating that the cation gating effect permits the uptake of $\mathrm{CO}_{2}$ but not $\mathrm{CH}_{4}{ }^{[7,8]}$
The framework of CHA type zeolites consists of double 6membered ring (D6R) and cha cage units, where the super cages (10 $\left.\times 8 \times 8 \AA^{3}\right)$ are interconnected by a 3-dimensional pore system with 8-membered ring $(8 \mathrm{MR})$ entries $\left(3.8 \times 3.8 \AA^{2}\right)$. ${ }^{[9]}$ The selective adsorption of $\mathrm{CO}_{2}$ in $\mathrm{CHA}$ zeolites containing various cations $\left(\mathrm{K}^{+}, \mathrm{Rb}^{+}\right.$, or $\mathrm{Cs}^{+}$) have been investigated demonstrating that the cations controlling the adsorption of $\mathrm{CO}_{2}$ over $\mathrm{CH}_{4}$ are the ones located at the centre of the $8 \mathrm{MRs}$. Their high separation ability was attributed to cation gating behaviour described as a molecular "trapdoor" mechanism. ${ }^{[10-13]}$ Shang et al. ${ }^{[6]}$ proposed that $\mathrm{CO}_{2}$ and $\mathrm{CO}$ interact strongly with the 8MR door-keeping cations $\left(\mathrm{K}^{+}, \mathrm{Rb}^{+}, \mathrm{Cs}^{+}\right)$due to their respective quadrupole and dipole moment and higher polarizability as compared to $\mathrm{N}_{2}$ and $\mathrm{CH}_{4}$. This interaction displaces the door-keeping cations located at site SIII' (Figure 1a) from the 8MR, allowing the selective entry of molecules into the super cage of the CHA zeolite. The cation displacement is temporary and reversible, thus the "weakly" interacting molecules such as $\mathrm{CH}_{4}$ and $\mathrm{N}_{2}$ are excluded while $\mathrm{CO}$ and $\mathrm{CO}_{2}$ are selectively adsorbed. Shang et al. ${ }^{[11]}$ determined that a $\mathrm{CHA}$ zeolite with an $\mathrm{Si} / \mathrm{Al}$ ratio lower than 3 will display "trapdoor" behaviour for the selective $\mathrm{CO}_{2}$ adsorption from a mixture containing $\mathrm{CH}_{4}$ provided the extra-framework cations are located at the centre of the 8MRs.

So far, CHA type zeolites have been synthesised using organic structure-directing agents (OSDAs), ${ }^{[14]}$ seeds ${ }^{[15]}$ or by recrystallization of $\mathrm{H}-\mathrm{FAU}$ zeolite to K-CHA under alkaline treatment. ${ }^{[16]}$ Previously, Liu et al. ${ }^{[17]}$ reported the synthesis of OSDA-free pure CHA-type zeolite using $\mathrm{NH}_{4} \mathrm{~F}$. This method affords micron-sized crystals of 15-20 $\mu \mathrm{m}$ with a low amount of defects, however, the large size of the crystals affects their performance in gas adsorption ${ }^{[18]}$ and catalysis ${ }^{[19]}$ due to diffusion limitations. Up to now, nanosized $\mathrm{CHA}$ zeolite has been obtained either by recrystallization of FAU-type zeolite synthesized with the assistance of an OSDA ${ }^{[20]}$ or by ball milling. ${ }^{[21]}$ We here report on the OSDA-free synthesis of a CHA type zeolite with excellent $\mathrm{CO}_{2}$ sorption capacity and selectivity. 

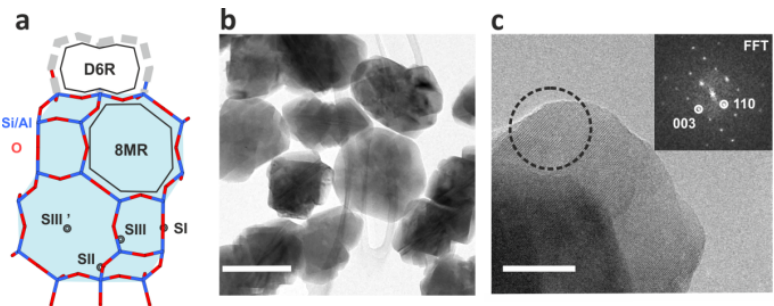

d

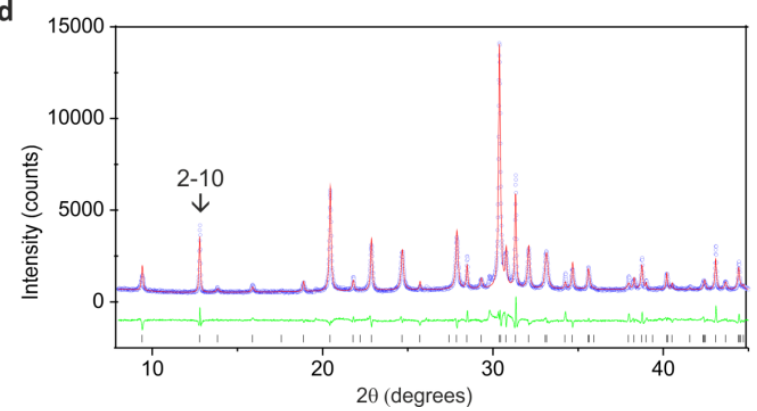

Figure 1. Identification of nanosized CHA. a, CHA framework (SG: $R-3 m$ ) projected along the $b$-axis showing the super cage (in light blue). Bonds between Si/AI (tetrahedral sites) and oxygens, D6R and 8MR units and sites for extra-framework cations (denoted S) are indicated for clarity. b, TEM image of nanosized $\mathrm{CHA}$ crystals synthesized without OSDAs in aqueous solution under hydrothermal synthesis conditions $\left(90^{\circ} \mathrm{C}\right.$ for $8 \mathrm{~h}$ ). Length of the scale bar is 200 $\mathrm{nm}$. c, High-resolution TEM image of a crystallite looking along [1-10]. Length of the scale bar is $40 \mathrm{~nm}$. Inset: Fourier transform from the area encircled in black. d, Le Bail refinement of the powder X-ray diffraction pattern of the assynthesized CHA nanosized crystals.

Nanosized CHA type zeolite crystals with a size below $200 \mathrm{~nm}$ and a Si/Al ratio of 2.0 are obtained by direct hydrothermal treatment of colloidal precursor suspensions containing a mixture of inorganic structure directing cations only $\left(\mathrm{Na}^{+}, \mathrm{K}^{+}\right.$and $\left.\mathrm{Cs}^{+}\right)$. The nanosized $\mathrm{CHA}$ crystals with plate-like morphology are shown in Figure $\mathbf{1 b}$ and $\mathbf{c}$. The mixed inorganic cations were not only used to prepare the clear colloidal precursor suspensions, but also to prevent Ostwald ripening ${ }^{[22]}$ during the crystallization process and facilitate the formation of nanosized CHA crystals. The use of the mixture of three inorganic cations $\left(\mathrm{Na}^{+}, \mathrm{K}^{+}\right.$and $\left.\mathrm{Cs}^{+}\right)$is required, and their concentration was fine-tuned in order to synthesize nanosized $\mathrm{CHA}$ zeolite crystals free of impurities (Figure 1d, Table S1). The formation of secondary phases, such as RHO or FAU type zeolites, was avoided by optimizing the chemical composition of the colloidal precursor suspensions and the physical parameters controlling the synthesis (time of aging, speed of stirring, and synthesis temperature) (Table S1). The Le Bail refinement of the powder X-ray diffraction (PXRD) pattern (Figure 1d) using the space group $R-3 m$ confirmed that single phase $\mathrm{CHA}$ zeolite was synthesized. The refinement also revealed the presence of anisotropic peak broadening due to the plate-like shape of the crystallites and a certain degree of structural disorder. The size of the CHA crystallites, as estimated by the Scherrer equation, ${ }^{[23]}$ is approximately $42 \mathrm{~nm}$ (thickness, along the $c$-axis) by $189 \mathrm{~nm}$ (width, in the ab-plane) which is in agreement with the HRTEM observations. Furthermore, the NMR spectroscopic results confirmed the formation of crystalline CHA zeolite. The ${ }^{27} \mathrm{Al}$ NMR spectrum contains only one peak at $57.8 \mathrm{ppm}$ corresponding to tetrahedrally coordinated Al (Figure S1), while the ${ }^{29} \mathrm{Si}$ NMR spectrum contains peaks at -89.3 ppm, -93.6 ppm, -99.1 ppm, -104.6 ppm and -109.1 ppm corresponding to $\mathrm{Q}^{0}(4 \mathrm{Al}), \mathrm{Q}^{1}(3 \mathrm{Al}), \mathrm{Q}^{2}(2 \mathrm{Al}), \mathrm{Q}^{3}(1 \mathrm{Al})$ and $\mathrm{Q}^{4}$ (0Al) silicon tetrahedrally coordinated, respectively. ${ }^{[24]} \mathrm{A} \mathrm{Si} / \mathrm{Al}$ ratio of 2.0 was estimated according to the equation of Engelhardt and Michel using the ${ }^{29}$ Si NMR data. ${ }^{[25]}$
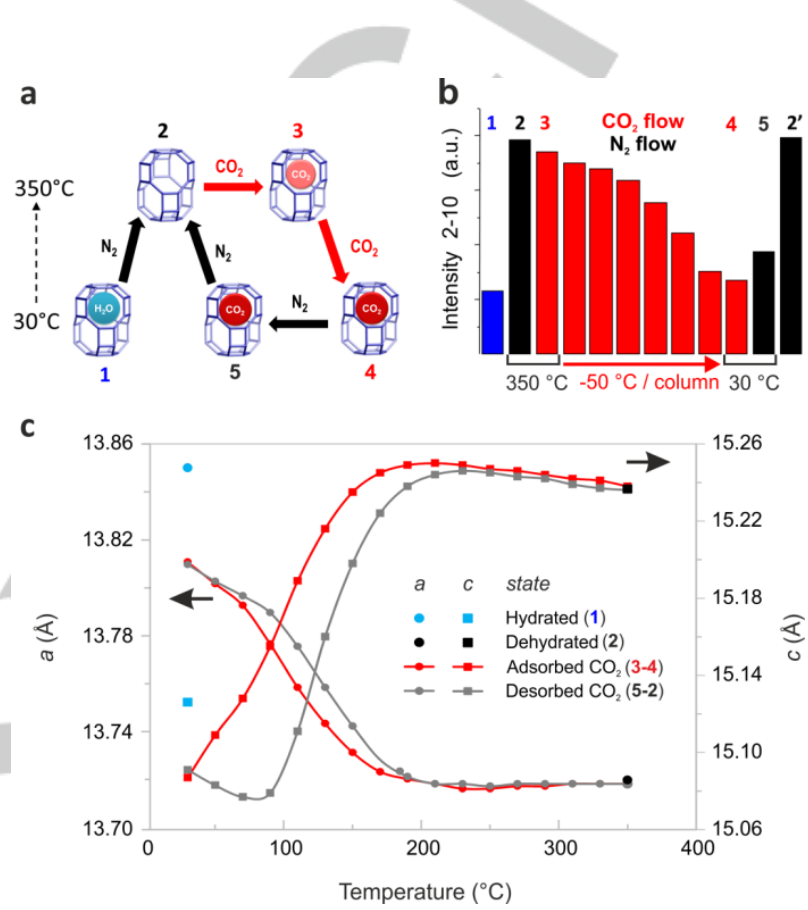

Figure 2. In-situ PXRD study. CHA nanocrystals were subjected to adsorption of $\mathrm{CO}_{2}$ after activation $\left(350{ }^{\circ} \mathrm{C}\right.$ under $\mathrm{N}_{2}$ ): (a) schematic representation of the measurement cycles at different temperatures and atmospheres. The assynthesized $\mathrm{CHA}$ was activated under heating at $350^{\circ} \mathrm{C}$ (Steps 1 to 2). Then the samples were measured at $350{ }^{\circ} \mathrm{C}$ under $\mathrm{CO}_{2}$ flow $\left(40 \mathrm{~mL}\right.$. $\mathrm{min}^{-1}$ keeping the pressure at 1 bar) with decreasing the temperature until room temperature (Steps 3 to 4). The $\mathrm{CHA}$ was reactivated under heating at $350{ }^{\circ} \mathrm{C}$ to desorb the $\mathrm{CO}_{2}$ molecules (Steps 5 to 2 '). More details are provided in the experimental section (method). b, Change of the diffraction intensity of 2-10 reflection at $12.8^{\circ}$ (20) over the measurement cycle. c, Evolution of the unit-cell parameters a (disks) and $c$ (squares) vs temperature and atmospheres.

The mechanism of selective $\mathrm{CO}_{2}$ adsorption by OSDA-free nanosized $\mathrm{CHA}$ zeolite was investigated by several complementary in situ methods. Initially, the changes to the crystallographic properties of the nanosized $\mathrm{CHA}$ crystals under adsorption of $\mathrm{CO}_{2}$ were studied by in situ PXRD. The measurements were performed following a protocol schematically presented in Figure $2 \mathbf{a}$. The nanosized CHA zeolite was activated in the in situ cell under $\mathrm{N}_{2}$ atmosphere (1 bar) at $350{ }^{\circ} \mathrm{C}$, then $\mathrm{CO}_{2}$ ( 1 bar) was delivered under gradual decrease of the temperature from $350{ }^{\circ} \mathrm{C}$ to room temperature (RT). Dehydration of the as-prepared $\mathrm{CHA}$, was confirmed by an increase of the intensity of the Bragg peak at $12.8^{\circ} 2 \theta$ corresponding to the $2-10$ reflection (Figure 2b), a decrease of the a lattice parameter and an increase of the $c$ lattice parameter (Figure 2c). These parameters are sensitive to the presence of adsorbed molecules and can be used to monitor 
$\mathrm{CO}_{2}$ adsorption as a function of temperature. As shown in Figure 2c, the adsorption of $\mathrm{CO}_{2}$ begins to occur at approximately $200^{\circ} \mathrm{C}$. This agrees well with the thermogravimetric analyses (TGA) carried out following the same protocol (Figure 3a). Based on the TGA, the number of $\mathrm{CO}_{2}$ and $\mathrm{H}_{2} \mathrm{O}$ molecules per unit cell was estimated to be 8 and 28 for $\mathrm{CO}_{2}$-loaded and hydrated nanosized $\mathrm{CHA}$ zeolite sample, respectively (Table S2). In addition, TGA (Figure 3a) over 10 cycles of $\mathrm{CO}_{2}$ adsorption/desorption show that the sorption capacity of the nanosized $\mathrm{CHA}$ zeolite is fully preserved. The high stability and regenerability of the nanosized $\mathrm{CHA}$ zeolite is also confirmed by the absence of any changes in the PXRD patterns of the sample after 10 cycles (Figure S2). The nanosized CHA zeolite adsorbed $3.8 \mathrm{mmol} / \mathrm{g}$ $\mathrm{CO}_{2}$ at $121 \mathrm{kPa}$ and $273 \mathrm{~K}$ (Figure S3) which is significantly higher than the Cs-CHA prepared by ion exchange from OSDA synthetized $\mathrm{CHA}(<2.5 \mathrm{mmol} / \mathrm{g} \text { at } 253 \mathrm{~K})^{[6]}$ and similar to the pure $\mathrm{K}-\mathrm{CHA}$ zeolite $\left(>4 \mathrm{mmol} / \mathrm{g}\right.$ ). This value is also comparable with the maximum $\mathrm{CO}_{2}$ uptake obtained in SSZ-13 (CHA type) zeolites. ${ }^{[26,27]}$ After demonstrating the high $\mathrm{CO}_{2}$ adsorption capacity of the nanosized $\mathrm{CHA}$ type zeolite, the selectivity was investigated by studying the adsorption of $\mathrm{CH}_{4}$. The nanosized $\mathrm{CHA}$ zeolite demonstrated high selectivity for $\mathrm{CO}_{2}$ over $\mathrm{CH}_{4}$ as shown by both TGA (Figure 3) and in situ FTIR (Figure S4) experiments. The selective $\mathrm{CO}_{2}$ adsorption in the CHA zeolite is confirmed by the presence of a band at $2345 \mathrm{~cm}^{-1}$ corresponding to the physisorbed $\mathrm{CO}_{2}$, and bands in the range 1316$1680 \mathrm{~cm}^{-1}$ representing the chemisorbed $\mathrm{CO}_{2}$ (Figure S4a). $\mathrm{No} \mathrm{CH}$ bands in the region $2700-2900 \mathrm{~cm}^{-1}$ corresponding to $\mathrm{CH}_{4}$ are present in the IR spectra (Figure S4b). In terms of the $\mathrm{CO}_{2}$ adsorption capacity and selectivity, the performance of the nanosized $\mathrm{CHA}$ rivals the best CHA zeolites synthesized using OSDA. ${ }^{[26-27]}$ This goal is reached without the need for high-temperature calcination (above 500 ${ }^{\circ} \mathrm{C}$ ) to eliminate the OSDA and post-synthetic ion exchange to ensure $\mathrm{CO}_{2}$ selectivity.

a

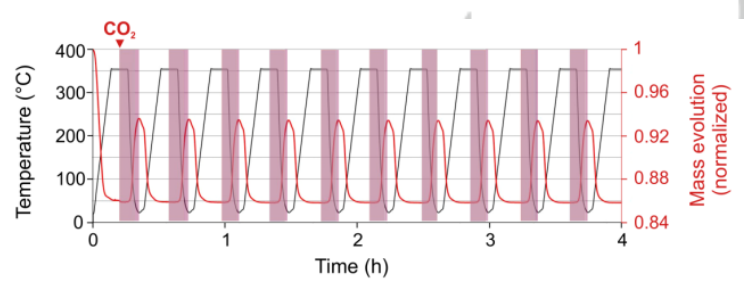

b
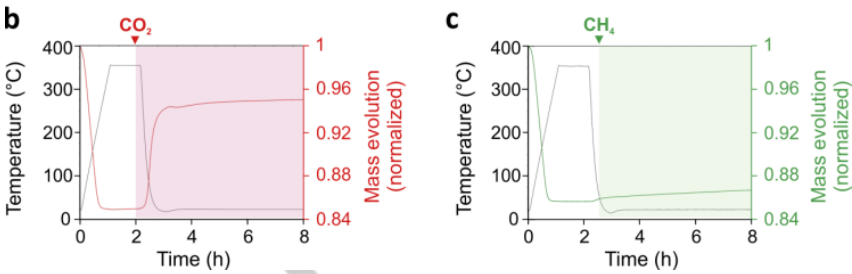

Figure 3. $\mathrm{CO}_{2}$ vs $\mathrm{CH}_{4}$ absorption. a, Thermogravimetric analysis (TGA) of nanosized $\mathrm{CHA}$ zeolite subjected to 10 consecutive adsorption/desorption cycles of $\mathrm{CO}_{2}$ : temperature variation (black line), $\mathrm{CO}_{2}$ sorption (red rectangles) and mass variation (red line). b, mass variation upon $\mathrm{CO}_{2}$ adsorption (red line) and (c) $\mathrm{CH}_{4}$ adsorption (green line) on as-synthesized nanosized $\mathrm{CHA}$. The $\mathrm{CH}_{4}$ flow was delayed and started at $25^{\circ} \mathrm{C}$ instead of $350{ }^{\circ} \mathrm{C}$ for safety reasons.
To gain further insight into the selective $\mathrm{CO}_{2}$ adsorption by the nanosized $\mathrm{CHA}$, a single crystal structure investigation was performed on a $\mathrm{CO}_{2}$ loaded sample in order to obtain a complete structure determination including the localization of extra-framework cations and guest molecules $\left(\mathrm{CO}_{2}\right)$. In the past, the fine structure of Chabazite was investigated by single crystal $X$-ray diffraction. ${ }^{[28]}$ In our case, due to the small size of the CHA nanocrystals (less than $10^{-2} \mu \mathrm{m}^{3}$ ), structure analysis based on precession-assisted $3 \mathrm{D} \mathrm{ED}^{[29]}$ was carried out. The measurements of six different nanosized single crystals were combined to obtain a high-quality data set (Table S3). The electrostatic potential map obtained by ab initio structure solution (charge flipping method ${ }^{[30]}$ ) revealed two occupied extra-framework sites: Site SIl above the D6R with oxygen distances of about $2.8 \AA$ and Site SIII' at the center of the 8MR with oxygen distances between 3.2 and $3.5 \AA$ (Figure 4). Taking dynamical diffraction effects into account, ${ }^{[31]}$ a structural model for the nanosized $\mathrm{CHA}$ zeolite was refined with an overall composition of $\mathrm{Cs}_{6.61(2)} \mathrm{K}_{3.6} \mathrm{Na}_{2.4}\left(\mathrm{Si}_{23.4} \mathrm{Al}_{12.6}\right) \mathrm{O}_{72}\left(\mathrm{CO}_{2}\right)_{8}$, which is in agreement with the chemical composition $\mathrm{Cs}_{6.3(4)} \mathrm{K}_{3.6(2)} \mathrm{Na}_{2.5(5)}\left(\mathrm{Si}_{23.6(9)} \mathrm{Al}_{12.4(7)}\right) \mathrm{O}_{72}\left(\mathrm{CO}_{2}\right)_{8.0(3)}$ determined by EDX combined with TGA.

a

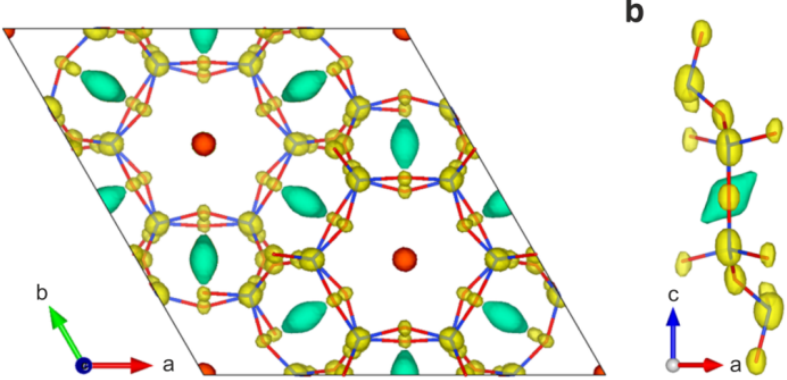

C

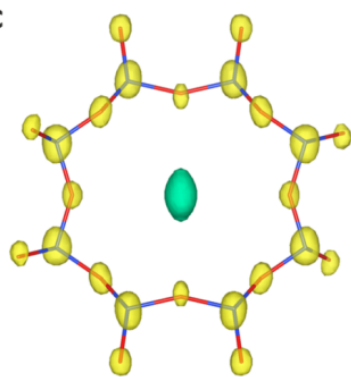

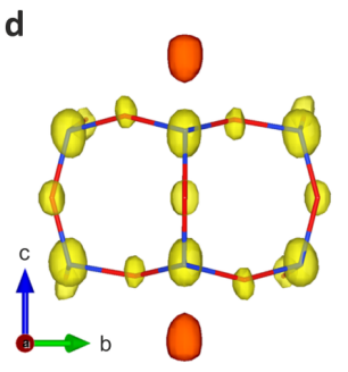

d
Figure 4. Structure solution. Electrostatic potential map obtained from ab initio structure solution using single nanocrystals PEDT datasets. Isosurface levels correspond to $3.5 \sigma[V(r)]$. a, Projection along $c$. Yellow, red and green transparent colours indicate framework, SII and SIII' sites, respectively. Tetrahedral sites (blue lines) and framework oxygen atoms (red lines) are included for clarity. $\mathbf{b}$, Side view of eight membered ring (8MR) with elongated potential around SIII' site. c, Perpendicular view of 8MR. d, Side view of D6R with SII sites. 
The refinement results (more details in Supporting Information) indicate that the SII site is a split site occupied by $\mathrm{Na}(40 \%)$ and $\mathrm{K}$ (60\%), whereas the SIII' site is partially occupied by $73.4(3) \%$ Cs only (Table S4 and Figure S5). Despite having less than $1 \mathrm{Cs}^{+}$cation per 8MR, this CHA zeolite exhibits an overall molecular "trapdoor" effect that prevents $\mathrm{CH}_{4}$ to be adsorbed. ${ }^{[11]} \mathrm{A}$ remarkable feature illustrating the role of the $\mathrm{Cs}^{+}$cation in the "trapdoor" effect is that the mean atomic displacement parameter of the $\mathrm{Cs}^{+}$cation perpendicular to the $8 \mathrm{MR}$ door is very large $\left(U_{\perp}=0.346 \AA^{2}\right)$ compared to the displacements parallel to the $8 \mathrm{MR}\left(U_{\|}=0.019\right.$ and $\left.0.030 \AA^{2}\right)$. $\mathrm{Cs}^{+}$cations are strongly displaced back and forth from the center of the 8MR site even at low temperature $(T=100 \mathrm{~K})$. This is consistent with previous NMR measurements and DFT calculations on Cs-exchanged $\mathrm{CHA}$ where the $\mathrm{Cs}^{+}$cations were reported to demonstrate greater mobility in the presence of $\mathrm{CO}_{2}{ }^{[6]}$ The possibility to have such an atomic displacement induced by the electron beam can be disregarded as similar behavior is confirmed from Rietveld refinement based on the PXRD data recorded at room temperature (see Supporting Information). This tendency of the door-keeping cation to move away from its average position allows some molecules to go through and enter the supercage. After the completion and refinement of the host structure, the difference potential map revealed the position of the $\mathrm{CO}_{2}$ guest molecules within the cha supercage (Figure 5). Even though the individual atoms were not well discernible, the position of the $\mathrm{CO}_{2}$ molecule refined to reasonable values, and the refinement was stable with a minimum set of constraints on the molecule geometry (Tables $\mathbf{S} 5$ and $\mathbf{S 6}$ ). The $\mathrm{CO}_{2}$ molecules are approximately aligned with the long axis of the $\mathrm{CHA}$ unit cell and coordinate the extra-framework cations. The shortest host-guest contacts are 2.621(12) $\AA$ for $\mathrm{CO}_{2}-\mathrm{K}^{+}$and 3.105(9) $\AA$ for $\mathrm{CO}_{2}-\mathrm{Cs}^{+}$(Table S7). This is, to our knowledge, the first direct determination of the $\mathrm{CO}_{2}$ position in CHA zeolite with low Si/Al ratio. Notably, this position is different from any of the positions found in $\mathrm{Li}-, \mathrm{Na}-$ and $\mathrm{K}-\mathrm{CHA}$ zeolites using neutron powder diffraction data ${ }^{[9]}$, where $\mathrm{CO}_{2}$ is located predominantly in the center of the 8MR at site SIIl'. Noteworthy, the refined $\mathrm{CO}_{2}$ position, the $\mathrm{CO}_{2}-\mathrm{Cs}^{+}$distance and the increased mobility of Cs due to the presence of guest $\mathrm{CO}_{2}$ are consistent with first principle calculations performed for low Si/Al ratio Cs-CHA zeolites. ${ }^{[32]}$ The position of the $\mathrm{CO}_{2}$ molecules was also confirmed by Rietveld refinement of PXRD data (Tables S8-S9 and Figure S8), complementing the ED results. These structural results are further supported by the superposition of the calculated micropore volume of the cha cage and the refined position of the $\mathrm{CO}_{2}$ molecule (Figure 5). a
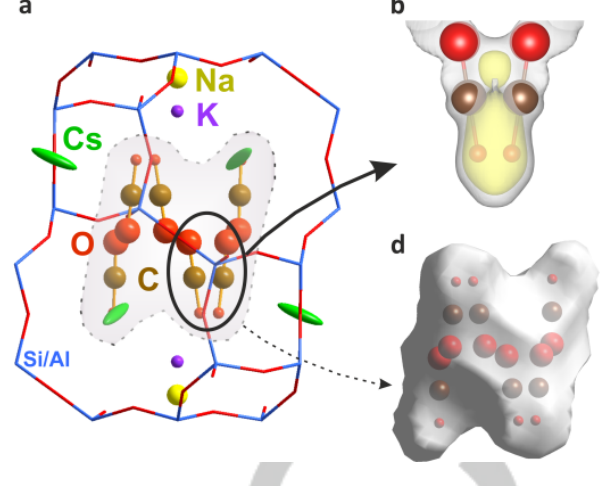

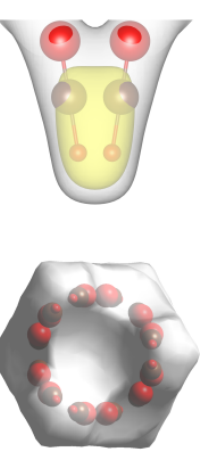

Figure 5. $\mathrm{CO}_{2}$ position in nanosized $\mathrm{CHA}$ zeolite probed by electron diffraction. a, Projection of the refined structure along the a direction showing the localization of $\mathrm{CO}_{2}$ molecules inside the super cage. The plotted atom size represents a probability sphere of $40 \%$ for the extra-framework cations and $10 \%$ for the $\mathrm{CO}_{2}$ molecules based on refined ADPs. b, Overlay of difference potential map (grey and yellow isosurface levels correspond to $2 \sigma[\Delta \mathrm{V}(\mathrm{r})]$ and $3 \sigma[\Delta \mathrm{V}(\mathrm{r})]$, respectively) and the refined position of the $\mathrm{CO}_{2}$ molecule. c, Expected potential map based on calculated structure factors. In (d) and (e), the positions of the $\mathrm{CO}_{2}$ molecules are superimposed on the void volume of the cha cage along a and $c$ direction, respectively. The occupancy of each displayed $\mathrm{CO}_{2}$ molecule is $22.2 \%$, i.e. on average only 2.67 of the 12 shown molecule sites are occupied.

Eight $\mathrm{CO}_{2}$ molecules per unit cell correspond to $\sim 2.5 \mathrm{mmol} / \mathrm{g}$, which is less than the measured sorption capacity at ambient pressure (Figure S3). We identified a similar discrepancy between the crystallographic results and sorption measurements in the work by Pham et al. ${ }^{[27]} \mathrm{A}$ likely explanation is that crystallographic studies are only sensitive to $\mathrm{CO}_{2}$ molecules that are adsorbed inside the zeolite crystals, i.e. in the cages. However, $\mathrm{CO}_{2}$ is adsorbed in the mesopores between the $\mathrm{CHA}$ nanocrystals (textural mesopores) and at the surface of the crystals that increases the amount of the measured $\mathrm{CO}_{2}$. From single crystal diffraction data, ${ }^{[33]}$ the estimated volume needed by a single $\mathrm{CO}_{2}$ molecule in a solid is $\sim 44.5 \AA^{3}$. Considering the $\mathrm{CHA}$ framework and extra-framework cations, the volume accessible to $\mathrm{CO}_{2}$ molecules is approximately $500 \AA^{3}$ per unit cell, which corresponds to a maximum of about $11 \mathrm{CO}_{2}$ molecules per unit cell. About $73 \%$ of this hypothetical upper limit is reached in our nanosized $\mathrm{CHA}$ zeolite sample. Taking inter-atomic distances into account, any so far reported $\mathrm{CO}_{2}$ site in $\mathrm{CHA}^{[27]}$ does not allow to host more than 9 molecules per unit cell (see Supporting Information). This limit is obeyed in $\mathrm{CHA}$ zeolites with $\mathrm{Si} / \mathrm{Al}=6-12$ reported by Pham et al. ${ }^{[27]}$ The refined number of molecules is $\sim 8.2$ for both $\mathrm{Li}$ - and $\mathrm{Na}$ $\mathrm{CHA}, \sim 5.5$ for pure Si-CHA (all three based on powder neutron diffraction at $T=10 \mathrm{~K}$ ) and $\sim 6.0$ for $\mathrm{K}-\mathrm{CHA}$ (based on PXRD). However, the majority of the molecules in all these zeolites occupies the $8 \mathrm{MR}$, rendering the desirable trapdoor effect impossible. Thus, with $8 \mathrm{CO}_{2}$ per unit cell, the $\mathrm{CHA}$ zeolite of this work reaches an almost perfect $\mathrm{CO}_{2}$ storage capacity together with the excellent selectivity (no $\mathrm{CH}_{4}$ was adsorbed)

In summary, we report the direct and environmentally benign synthesis of nanosized $\mathrm{CHA}$ zeolite $(\mathrm{Si} / \mathrm{Al}=2)$ without the use of OSDAs. A mixture of three alkali cations, $\mathrm{Cs}^{+}, \mathrm{K}^{+}$and $\mathrm{Na}^{+}$, was used as an inorganic templating agent to direct the synthesis of the 
nanosized CHA zeolites, and in particular $\mathrm{Cs}^{+}$was employed as the primary cation responsible for the selective adsorption of $\mathrm{CO}_{2}$ over $\mathrm{CH}_{4}$. In addition to the improvement in the pore accessibility and the adsorption kinetics, the nanosized $\mathrm{CHA}$ zeolite demonstrated a high $\mathrm{CO}_{2}$ absorption capacity. Moreover, the $\mathrm{Cs}^{+}$cations improve the stability of the $\mathrm{CHA}$ structure, demonstrating recyclability under high temperature treatment and multi-cycle $\mathrm{CO}_{2}$ adsorption experiments. This environmentally benign synthesis of $\mathrm{CHA}$ nanocrystals is energyefficient and more affordable than other methods reported so far in the open literature. Potentially scalable for industrial applications, the nanosized $\mathrm{CHA}$ zeolite is a highly promising material for applications in both $\mathrm{CO}_{2}$ capture and $\mathrm{CO}_{2} / \mathrm{CH}_{4}$ separation.

\section{Acknowledgements}

Financial support from CARNOT ESP (project NZAMS-CO2), TOTAL and Industrial Chair ANR-TOTAL "Nanoclean Energy" is acknowledged, as well as from the Normandy Region through the RIN Recherche Program. The work at loP Prague was performed withing CzechNanoLab Research Infrastructure supported by MEYS CR (LM2018110) using instruments of the ASTRA laboratory established within the Operation program Prague Competitiveness project CZ.2.16/3.1.00/24510 and supported by the Czech Science Foundation, project number 19-08032S.

Keywords: Nanozeolites $\bullet$ Template-free synthesis $\bullet \mathrm{CO}_{2}$ adsorption - $\mathrm{CO}_{2}$ In-situ PXRD • precession-assisted 3D ED.

[1] M. Fischedick, J.Roy, Climate Change 2014: Mitigation of Climate Change, in Chapter 10 - Industry. IPCC Working Group III Contribution to AR5 (Cambridge University Press, 2014).

[2] Tracking Clean Energy Progress. https://www.iea.org/topics/trackingclean-energy-progress.

[3] H. A. Patel, J. Byun, C. T. Yavuz, Carbon Dioxide Capture Adsorbents: Chemistry and Methods. ChemSusChem, 2017, 10,1303-1317

[4] M.C. Bacariza, I. Graça, J.M. Lopes, C. Henriques. Tuning Zeolite Properties towards CO2 Methanation: An Overview. ChemCatChem, 2019, 11, 2388-2400.

[5] M. Dusselier, and M.E. Davis, Small-Pore Zeolites: Synthesis and Catalysis. Chem. Rev. 2018,118, 5265-5329.

[6] J. Li. Shang, R. Singh, Q. Gu, K. M. Nairn, T. J. Bastow, N. Medhekar, C. M. Doherty, A. J. Hill, J. Z. Liu, P. A. Webley, Discriminative separation of gases by a 'molecular trapdoor' mechanism in chabazite zeolites. J. Am. Chem. Soc., 2012, 134, 19246-19253.

[7] V. M. Georgieva, L. E. Bruce, M.C. Verbraeken, A. R. Scott, W. J. Casteel, Jr. S. Brandani, P.A. Wright, Triggered Gate Opening and Breathing Effects during Selective $\mathrm{CO}_{2}$ Adsorption by Merlinoite Zeolite. J. Am. Chem. Soc. 2019, 141, 12744-12759.

[8] M. Palomino, A. Corma, J. L. Jordá, F. Rey, S. Valencia, Zeolite Rho: a highly selective adsorbent for $\mathrm{CO}_{2} / \mathrm{CH}_{4}$ separation induced by a structural phase modification. Chem. Commun. 2012, 48, 215-217.

[9] L. Smith, H. Eckert, A. K. Cheetham, Site Preferences in the Mixed Cation Zeolite, Li,Na-Chabazite: A Combined Solid-State NMR and Neutron Diffraction Study. J. Am. Chem. Soc. 2000, 122, 1700-1708.

[10] T. Du, X. Fang, L. Liu, J. Shang, B. Zhang, Y. Wei, H. Gong, S. Rahman, E. F. May, P. A. Webley, G. Li, An optimal trapdoor zeolite for exclusive admission of $\mathrm{CO}_{2}$ at industrial carbon capture operating temperatures. Chem. Commun. 2018, 54, 3134-3137.

[11] J. Shang, G. Li, R. Singh, P. Xiao, J. Z. Liu, P. A. Webley, Determination of Composition Range for "Molecular Trapdoor" Effect in Chabazite Zeolite. J. Phys. Chem. C, 2013, 117, 12841-12847.

[12] J. Shang, G. Li, R. Singh, P, Xiao, D. Danaci, J. Z. Liu, P. A. Webley, Adsorption of $\mathrm{CO}_{2}, \mathrm{~N}_{2}$, and $\mathrm{CH}_{4}$ in Cs-exchanged chabazite: $A$ combination of van der Waals density functional theory calculations and experiment study. J. Chem. Phys. 2014, 140, 084705.

[13] G. Li, J. Shang, Q. Gu, R. V. Awati, N. Jensen, A. Grant, X. Zhang, D. S. Sholl, J. Z. Liu, and P. A. Webley, E.F. May, Temperature-regulated guest admission and release in microporous materials. Nat. Commun 2017, 8.

[14] S. I. Zones, Zeolite SSZ-13 and its method of preparation. US Patent 4, $1985,544,538$

[15] H. Imai, N. Hayashida, T. Yokoi, T. Tatsumi, Direct crystallization of CHA-type zeolite from amorphous aluminosilicate gel by seed-assisted method in the absence of organic-structure-directing agents. Microporous and Mesoporous Mater. 2014, 196, 341-348.

[16] M. Bourgogue, J-L. Guth, R. Wey, Process for the preparation of synthetic zeolites, and zeolites obtained by this process. US Pat. 1985 4503024. 10.

[17] B. Liu, Y. Zheng, N. Hu, T. Gui, Y. Li, F. Zhang, R. Zhou, X. Chen, H. Kita, Synthesis of low-silica CHA zeolite chabazite in fluoride media without organic structural directing agents and zeolites. Microporous Mesoporous Mater. 2014, 196, 270-276.

[18] S. Prodinger, R. S. Vermuri, T. Varga, B. P. McGrail, R. Kishan, M. A. Derewinski, Impact of chabazite SSZ-13 textural properties and chemical composition on $\mathrm{CO}_{2}$ adsorption applications. New J. Chem. 2016, 40, 4375-4385.

[19] Z. Li, M.T. Navarro, J. Martínez-Triguero, J. Yu, A. Corma, Synthesis of nano-SSZ-13 and its application in the reaction of methanol to olefins. Catal. Sci. Technol. 2016, 6, 5856-5863.

[20] T. Takata, N. Tsunoji, Y. Takamitsu, M. Sadakane, T. Sano, Nanosized $\mathrm{CHA}$ zeolites with high thermal and hydrothermal stability derived from the hydrothermal conversion of FAU zeolite. Microporous Mesoporous Mater. 2016, 225, 524-533.

[21] C. Anand, T. Kaneda, S. Inagaki, S. Okamura, H. Sakurai, K. Sodeyama, T. Matsumoto, Y. Kubota, T. Okubo, T. Wakihara Downsizing the K-CHA zeolite by a postmilling-recrystallization method for enhanced base-catalytic performance. New J. Chem. 2016, 40, 492496.

[22] S. Mintova, J.-P. Gilson, V. Valtchev, Nanoscale 2013, 5, 6693-6703

[23] A. L. Patterson, The Scherrer Formula for X-Ray Particle Size Determination. Phys. Rev. 1939, 56, 978-982.

[24] G. T. M. Kadja, I. R. Kadir, A. T. N. Fajar, V. Suendo, R. R. Mukti, Revisiting the seed-assisted synthesis of zeolites without organic structuredirecting agents: insights from the CHA case. RSC Adv. 2020, 10, 5304-5315,

[25] G. Engelhardt, D. Michel, in "High-Resolution Solid-State NMR of Silicates and Zeolites", Wiley \& Sons, New York, 1987.

[26] M.R. Hudson, W.L. Queen, J.A. Mason, D.W. Fickel, R.F. Lobo, C.M. Brown, Unconventional, highly selective $\mathrm{CO}_{2}$ adsorption in zeolite SSZ13. J. Am. Chem. Soc. 2012, 134, 1970-1973.

[27] T. D. Pham, M. R. Hudson, C. M. Brown, R. F. Lobo, Molecular Basis for the High $\mathrm{CO}_{2}$ Adsorption Capacity of Chabazite Zeolites. ChemSusChem, 2014, 7, 3031-3038.

[28] L.S. Dent, J.V. Smith, Crystal structure of chabazite, a molecular sieve. Nature, 1958, 181, 1794-1796.

[29] M. Gemmi, E. Mugnaioli, T. E. Gorelik, U. Kolb, L. Palatinus, P. Boullay, S. Hovmöller. J. P. Abrahams, 3D Electron Diffraction: The Nanocrystallography Revolution. ACS Cent. Sci. 2019, 5, 1315-1329.

[30] L. Palatinus, G. Chapuis, Superflip - a computer program for the solution of crystal structures by charge flipping in arbitrary dimensions. J. Appl. Cryst. 2007, 40, 786-790.

[31] L. Palatinus, C. A. Corrêa, G. Steciuk. D. Jacob, P. Roussel, P. Boullay, M. Klementová, M, Gemmi, J, Kopeček. M. C. Domeneghetti, F. Cámara, V. Petříček, Structure refinement using precession electron diffraction tomography and dynamical diffraction: tests on experimental data. Acta Cryst. 2015, B71, 740-751.

[32] J. Shang, G. Li, P.A. Webley, J.Z. Liu. A density functional theory study for the adsorption of various gases on a caesium-exchanged trapdoor chabazite. Comput. Mater. Sci. 2016, 122, 307-313.

[33] A. Simon, K. Peters, Single-Crystal Refinement of the Structure of Carbon Dioxide, Acta Crystallogr., 1980, B36, 2750-2751. 


\section{Entry for the Table of Contents}

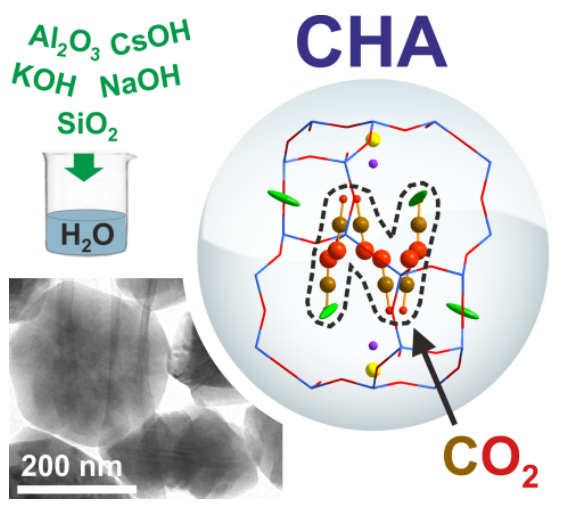

We report on the synthesis of nanosized $\mathrm{CHA}$ type zeolite without organic structure-directing agents. The zeolite material exhibits

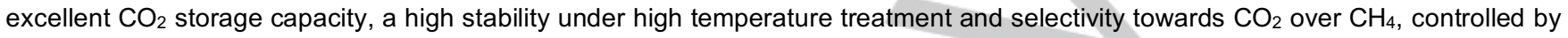
$\mathrm{Cs}+$ in the host structure. The environmentally benign and energy-efficient synthesis of CHA nanocrystals is more affordable than other methods reported so far in the open literature. 